University of Nebraska - Lincoln

DigitalCommons@University of Nebraska - Lincoln

Pseudoscorpions of the family Cheiridiidae (Arachnida: Pseudoscorpiones) recovered from burial sediments at Pachacamac (500-1,500CE), Peru

\author{
Johnica J. Morrow \\ University of Nebraska-Lincoln, Johnica.Morrow@sdsmt.edu \\ Livia Taylor \\ University of Nebraska-Lincoln \\ Lauren Peck \\ University of Nebraska-Lincoln \\ Christian Elowsky \\ University of Nebraska-Lincoln, celowsky@unl.edu \\ Lawrence Stewart Owens \\ University of London, lawrence_owens@yahoo.co.uk
}

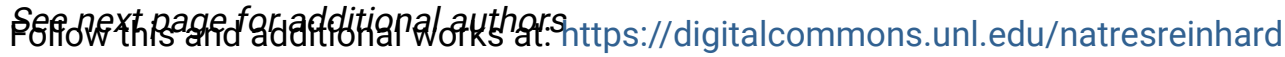

Part of the Archaeological Anthropology Commons, Ecology and Evolutionary Biology Commons, Environmental Public Health Commons, Other Public Health Commons, and the Parasitology Commons

Morrow, Johnica J.; Taylor, Livia; Peck, Lauren; Elowsky, Christian; Owens, Lawrence Stewart; Eeckout, Peter; and Reinhard, Karl, "Pseudoscorpions of the family Cheiridiidae (Arachnida: Pseudoscorpiones) recovered from burial sediments at Pachacamac (500-1,500CE), Peru" (2017). Karl Reinhard Papers/ Publications. 75.

https://digitalcommons.unl.edu/natresreinhard/75

This Article is brought to you for free and open access by the Natural Resources, School of at DigitalCommons@University of Nebraska - Lincoln. It has been accepted for inclusion in Karl Reinhard Papers/ Publications by an authorized administrator of DigitalCommons@University of Nebraska - Lincoln. 


\section{Authors}

Johnica J. Morrow, Livia Taylor, Lauren Peck, Christian Elowsky, Lawrence Stewart Owens, Peter Eeckout, and Karl Reinhard 


\title{
Pseudoscorpions of the family Cheiridiidae (Arachnida: Pseudoscorpiones) recovered from burial sediments at Pachacamac (500-1,500CE), Perú
}

\author{
Johnica J. Morrow ${ }^{1}$, Livia Taylor ${ }^{2}$, Lauren Peck ${ }^{1}$, Christian Elowsky ${ }^{3}$, Lawrence Stewart Owens ${ }^{4}$, Peter Eeckhout ${ }^{5}$, and \\ Karl J. Reinhard ${ }^{1}$ : ${ }^{1}$ Pathoecology Laboratory, School of Natural Resources, University of Nebraska-Lincoln, Lincoln, \\ Nebraska, USA. E-mail: johnica.morrow@unl.edu; ${ }^{2}$ Department of Anthropology, University of Nebraska-Lincoln, \\ Lincoln, Nebraska, USA; ${ }^{3}$ Department of Agronomy and Horticulture, University of Nebraska-Lincoln, Lincoln, \\ Nebraska, USA; ${ }^{4}$ History, Classics and Archaeology, Birkbeck College, University of London, 27-28 Russell Square, \\ London WC1B 5DQ, Great Britain; ${ }^{5}$ Département Histoire, Art et Archéologie, Orientation Amérique Précolombienne, \\ Université Libre de Bruxelles, Av. F. Roosevelt 50 (CP133/01), 1050 Brussels, Belgium
}

\begin{abstract}
Fragmented remains of pseudoscorpions belonging to the family Cheiridiidae (Arachnida, Pseudoscorpiones) were recovered from Ychsma polity (c. AD 1000-1475) burial sediments from Pachacamac, Perú. Sediments from 21 burials were examined following rehydration in $0.5 \%$ trisodium phosphate for $48 \mathrm{~h}$ and subsequent screening through a 250 $\mu \mathrm{m}$ mesh. Materials larger than $250 \mu \mathrm{m}$ were surveyed for the presence of arthropods. A total of two samples contained pseudoscorpion fragments, which were collected and quantified to determine the minimal number of pseudoscorpions present per gram of each sample. Following quantification, pseudoscorpion specimens were imaged utilizing confocal laser scanning microscopy (CLSM) to assist with identification efforts. Specimens have morphological characteristics consistent with those found in members of the pseudoscorpion family Cheiridiidae. Members of this family have not been previously described from archaeological materials recovered from Perú, and the implications of pseudoscorpions as members of the archaeological corpocenosis have not been fully interpreted. Herein, we report the first recovery of pseudoscorpions from archaeological materials at Pachacamac, and discuss the significance of their roles in the archaeological corpocenosis.
\end{abstract}

Keywords: Archaeoarchanology, burial sediments, corpocenosis, macrofossil analysis, confocal laser scanning microscopy

The corpocenosis, as defined by Morrow et al. (2016), is the community of organisms associated with corpses. In the present study, an analysis of burial sediments was conducted in order to further our understanding of the archaeological corpocenosis at Pachacamac. These sediments represented a series of Ychsma burials from Pachacamac, a large multiperiod site on the Peruvian Central Coast. Populated by a series of cultural groups including the Lima and the Inca, Pachacamac has been extensively excavated for over a century. Material used in the present study came from a current excavation project focusing upon the comparatively unknown Ychsma polity (c. AD 1000-1475). This is the first time that Ychsma interments - or any individual from the Central Coast - have been analyzed in this manner. Herein, we present the systematic sampling of 21 burials from Pachacamac. During these analyses, fragments of mites, insects, and pseudoscorpions were recovered from the burial sediments.

Archaeological background and field sampling.- - The site of Pachacamac covers approximately 600 ha at the mouth of the Lurin River, near modern Lima on the Central Coast of Peru. GPS coordinates for Pachacamac are as follows: $12.25983^{\circ} \mathrm{S}$, $76.899478^{\circ} \mathrm{W}$. The settlement was occupied for over a thousand years, to include the Early Intermediate Period/ EIP (ca. 200 BC-AD 600 [Lima culture]); the Middle Horizon/ MH (ca. AD 600-1000 [Wari culture]); the Late Intermediate Period/LIP (ca. AD 1000-1475 [Ychsma culture]); and the Late Horizon/LH (ca. AD 1475-1533 [Inca culture]). Each of these cultures built monumental structures and augmented the site's size and popularity, which reached Pan-Andean importance as a paramount pilgrimage center in the LH (Fleming 1983; Eeckhout 2003, 2013). The Ychsma Project was designed to investigate the function, development and influence of Pachacamac from the MH to the $\mathrm{LH}$, with special focus on monumental architecture and related material culture (Eeckhout 2000, 2003, 2013). Another important aspect of the site is its special relationship with the sphere of death, because several cemeteries are to be found within its boundaries, as well as burials within some of its buildings. Pachacamac is famous in Peruvian archaeology for being the first site to have been excavated using modern archaeological approaches. The stratigraphic sequence generated by Uhle (1903) was the first of its type in South America, and is still widely used today. This relative chronology considered not only architectural remains but also funerary data, with particular reliance upon superimposed burials of different periods in Cemetery I, at the foot of the temple of the eponymous god.

Several seasons of excavation and observation at the site indicate that the 'typical' grave is a basic pit, containing a few stones or used adobes to prop up or secure the body. There is no evidence of thatching, although there are some indications of mud plastering over light reed roofs. The most common variant, however, is collective burial, which follow a fairly consistent pattern. The basic foundation comprises an irregularly shaped, depressed chamber surrounded by several rough-cut poles that support a reed roof. The chamber was filled with bodies, usually in the seated or recumbent flexed "fetal" position and wrapped in textiles and/or reeds and rushes. Where original position could be determined, approximately $40 \%$ of burials were tightly flexed on their sides, with their arms wrapped around (or between) their legs. Most of the remainder showed signs of having originally been interred in a seated, crouched position, with their heads either upright 
Table 1.-Collection data and subsample weights for Pachacamac burial sediments containing pseudoscorpion fragments. Weight is expressed in grams $(\mathrm{g})$.

\begin{tabular}{lccccc}
\hline $\begin{array}{c}\text { Lab } \\
\text { ID }\end{array}$ & $\begin{array}{c}\text { Burial } \\
\text { Number }\end{array}$ & $\begin{array}{c}\text { Collection } \\
\text { Region }\end{array}$ & $\begin{array}{c}\text { Corpse } \\
\text { Age (years) }\end{array}$ & $\begin{array}{c}\text { Corpse } \\
\text { Sex }\end{array}$ & $\begin{array}{c}\text { Subsample } \\
\text { Weight }\end{array}$ \\
\hline P7 & E81 & Pelvis & $40-50$ & Female & 4.23 \\
P17 & E118 & Pelvis & 3.5 & Unknown & 0.58 \\
\hline
\end{tabular}

or resting on their knees, and their arms wrapped around their legs (Eeckhout \& Owens 2015a, b). Young children were often found in a supine, extended position, especially when associated with adults. Other burial styles include those previously described as 'deviant' by Eeckhout \& Owens (2008) - including cist burials, extended burials, and possible live burials - in that they flouted all the standards known for the period and the site.

Unfortunately, most potential information about burial customs has been lost because of severe and almost uninterrupted looting since the Spanish conquest. Nevertheless, during the 2004 field season, we found an intact $\mathrm{MH}$ to LIP sector of Cemetery I, which had been protected by rubble and collapsed LH structures. The funerary remains were from sealed contexts c. $2 \mathrm{~m}$ below the modern ground surface, which was bare of any vegetation cover. This precludes the possibility that the invertebrate remains recovered reflect modern infestation of the mummy bundles. This area proved to be extremely rich in burial remains, many of which truncated earlier layers and individuals. It seems that the desire to be buried in this location, just in front of the Temple of Ychsma (renamed Pachacamac by the Incas), was so great that people did not hesitate to disturb older graves in order to create new ones. This behavior has been provisionally attributed to Ychsma-Pachacamac's reputation as a curative deity, and receives some support from the unusually high number of individuals affected by serious diseases, especially in the upper levels of the sequence (Eeckhout \& Owens 2008; Owens \& Eeckhout 2015).

Arthropod analyses.-The discovery of pseudoscorpion fragments was serendipitous. Our sampling strategy was designed for the recovery of parasite eggs and dietary residues following the methods of Berg (2002) and Reinhard et al. (1986). However, the most informative remains recovered were arthropods. It appears that the proliferation of these organisms in the burial environment had reduced the preservation potential of parasite eggs and dietary residues.

Previous studies of archaeological materials have reported fragments of pseudoscorpions from archaeological contexts (Huchet 2010; Palla et al. 2011). These studies reported exuvia belonging to the superfamily Chthonioidea (Huchet 2010) and a single chela from a member of family Cheliferidae (Palla et al. 2011). Pseudoscorpions are often found in context with decomposing material because of their roles as predators of other arthropods associated with decomposition, such as the larvae of clothes moths, flies, carpet beetles, ants, small adult flies, and mites. These organisms may arrive at the bodies of dead animals via phoresy on a wide range of insects attracted to corpses and carrion. Herein, we report the first instance of nearly-complete specimens being recovered from Peruvian mummies and provide a quantitative analysis of organismal presence. These data are valuable for elucidating the role that pseudoscorpions play in the archaeological corpocenosis.

\section{METHODS}

Permission for analysis was granted to Professor Peter Eeckhout (ULB) by "Resolucion Directorial Nacional n ${ }^{\circ} 259 /$ INC", February 20, 2008, previously the Instituto Nacional de Cultura and now the Ministerio de Cultura. The remains assessed in the current publication are archaeologically derived but non-anthropogenic, being samples of organic food remains. Permits for analysis and study are covered under the terms of the original permission "Resolucion Directorial Nacional n²59/INC".

For this study, 41 soil samples were taken from 21 stratigraphically secure and intact burials (Table 1). Control samples from adjacent to the cranium and "coprolite" samples from the pelvic girdles were analyzed from 20 burials. One burial was represented by a pelvic sample only. In the laboratory, numbers were assigned to the samples with "A" designations referring to pelvic samples and " $B$ " designations referring to cranial samples. The plan was for the analysis of paired samples to provide a comparative basis to evaluate the dietary content of the "coprolite" samples. It was anticipated that the content of the control samples would allow us to distinguish which items reflected contaminants from the site that had filtered into the burials.

Samples were sorted, photographed and weighed. A subsample from each original sample was removed and placed in a contamination-free beaker for rehydration in $0.5 \%$ trisodium phosphate. The weights of the rehydration samples ranged from 5 to $15 \mathrm{~g}$. All samples were rehydrated for $48 \mathrm{~h}$. One Lycopodium spore tablet (batch 124961, containing approximately 12,540 Lycopodium spores) was dissolved in dilute hydrochloric acid for every $5 \mathrm{~g}$ of sample. These were added after rehydration had been achieved. Importantly, 11 of the "coprolite" samples produced copious black, opaque, viscous residues that would have prevented further analysis. To eliminate these residues, $4.0 \% \mathrm{KOH}$ was added to the beakers of rehydrating material. The rehydration colors for each sample were recorded. Each sample was subsequently disaggregated via a magnetic stirring apparatus. Disaggregated samples were then screened through a $250 \mu \mathrm{m}$ mesh screen while rinsing with distilled water. The material smaller than $250 \mu \mathrm{m}$ (microremains) was collected and concentrated via repeated centrifugation. The microremains were scanned for dietary residues and parasite eggs. The macroscopic remains (those materials larger than $250 \mu \mathrm{m}$ ) were dried on $12.5 \mathrm{~cm}$ diameter filter paper circles and examined stereoscopically for dietary and environmental fossils.

Macroremains were examined, sorted based on the type of material recovered, and fragments of arthropods were counted. Invertebrate fragments were stored in clean, appropriately-labeled $1 / 2$ dram vials with black, screwcap lids containing pulp-based seals. Pseudoscorpion fragment recovered were counted based on type (i.e., cephalothorax/abdomen fragment or appendage fragment). These counts were then used to determine the minimal number of individuals (MNI) present in each sample (Table 2). Given the MNI, the number of pseudoscorpions per gram of sediment was estimated using the original weight of the sample (Table 2). This determination 
Table 2.-Pseudoscorpion fragment counts, minimal number of individuals (MNI), and arachnid concentrations for Pachacamac burial sediments containing pseudoscorpion fragments. "Bodies" refers to the cephalothorax/abdomens of specimens recovered. "Appendages" refers to the individual disarticulated pedipalps of specimens recovered.

\begin{tabular}{lcccc}
\hline $\begin{array}{l}\text { Lab } \\
\text { ID }\end{array}$ & Bodies & $\begin{array}{c}\text { Appendages } \\
\text { (Pedipalps) }\end{array}$ & MNI & $\begin{array}{c}\text { Arachnid } \\
\text { Concentration }\end{array}$ \\
\hline P7 & 0 & 15 & 8 & 2 pseudoscorpions/gram \\
P17 & 31 & 5 & 31 & 53 pseudoscorpions/gram \\
\hline
\end{tabular}

of pseudoscorpion concentration is important for future comparative studies of the archaeological corpocenosis.

Images of select pseudoscorpion specimens were taken using a PC-mount JVC digital camera (KY-F75U) under a Leica stereoscope (10447177). The computer software Auto-Montage by Syncroscopy was used to create images of a few specimens (Fig. 1). Subsequently, other specimens were examined via confocal laser scanning microscopy (CLSM) (Figs. 2-4). A Nikon Eclipse 90i compound microscope equipped with a Nikon A1 confocal and associated NISElements 4.40 acquisition software was used to obtain images of both dorsal and ventral sides of pseudoscorpion specimens. Additionally, CLSM was used to capture images of a disarticulated pedipalp (Fig. 4). Channel 1 used an excitation of $404.7 \mathrm{~nm}$ with an emission range of $425-475 \mathrm{~nm}$ and is pseudocolored blue. Channel 2 features an excitation of 488 $\mathrm{nm}$ with an emission range of $425-475 \mathrm{~nm}$ and is pseudocolored green. Channel 3 features an excitation of $640.5 \mathrm{~nm}$ with an emission range of $425-475 \mathrm{~nm}$ and is pseudocolored red. The CLSM resulted in a red coloration of chitinous structures and a blue/green coloration of cuticular waxes. These images were used to highlight diagnostic morphological characteristics useful for specimen identification.

Identifications of the specimens were made based on morphological features using Legg \& Jones (1988), and Harvey $(1992,2013)$ as references. Identifications were later confirmed by Dr. Mark Harvey (Western Australian Museum, Perth).

\section{RESULTS}

A total of two samples examined from Pachacamac burials yielded fragments of pseudoscorpions (Tables 1, 2; Figs. 1-4). The majority of the remains were comprised of cephalothorax/ abdomens missing most of the appendages; however, partial pedipalps were also recovered. One of the pedipalp fragments retained the movable chelal finger, while the others displayed only the hand and fixed chelal finger (Fig. 4).

The MNI and pseudoscorpion concentration was calculated for each of the samples. Sample P17 contained the highest concentration of pseudoscorpions based on MNI counts (Table 2). Pseudoscorpion fragments were not found in the sample from the head region (P16) of the individual in Burial E-113 (Lab ID = P16 \& P17), but were abundant within the sample from the pelvic region (P17) (Table 2). The individual within this burial was a child of unknown sex who died around the age of 3.5 years (Table 1). Samples from the pelvic (P7) region of the individual in Burial 81 contained pseudoscorpion fragments. These fragments represented eight individual pseudoscorpions within the samples. The pseudoscorpion concentration for this sample was 53 pseudoscorpions/gram

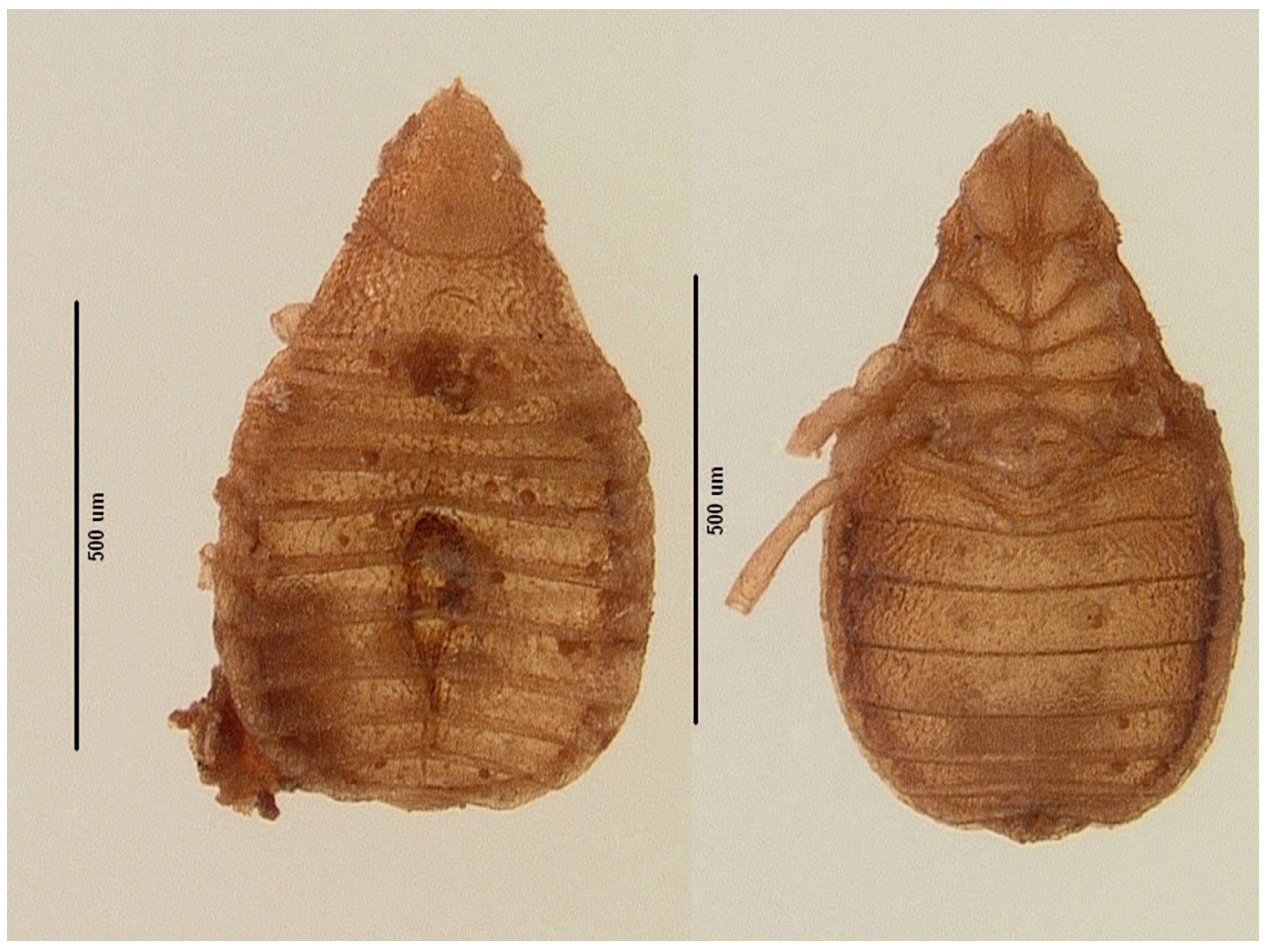

Figure 1.-Auto-Montage images of pseudoscorpions recovered from Pachacamac samples. Left to Right: dorsal view of specimen, ventral view of specimen. Scale bar $=500 \mu \mathrm{m}$. 


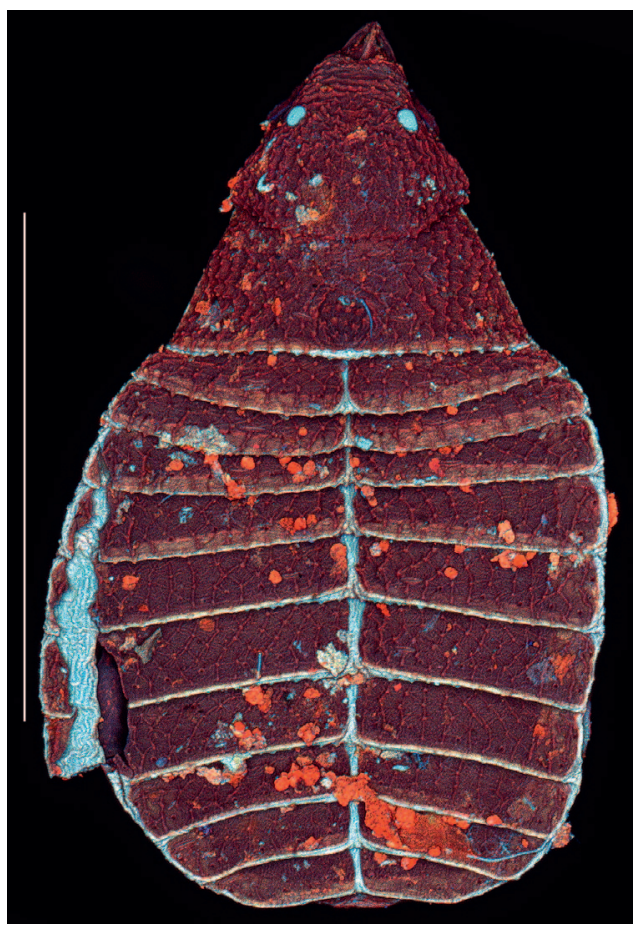

Figure 2.-Confocal laser scanning microscopy image of the dorsal view of a pseudoscorpion recovered from Pachacamac sample P17. Scale bar $=500 \mu \mathrm{m}$.

of burial sediment (Table 2). The individual in Burial 81 was a female who died between the ages of 40 and 50 years (Table 1).

Careful examinations of the morphological features of the specimens revealed that these pseudoscorpions belong in the family Cheiridiidae Hansen, 1894. These specimens possessed strongly granulate integuments, ten visible abdominal segments divided into separate halves, a subtriangular carapace, and a single pair of eyes on the cephalothorax. The specimens did not appear to possess V-shaped tergites or posterior expansions on coxa IV. Following this tentative designation, photographs of the specimens were sent to Dr. Mark Harvey of the Western Australian Museum, who concurred that these specimens belong within the family Cheiridiidae.

\section{DISCUSSION}

Previously, two studies examining material from mummies reported pseudoscorpion fragments (Huchet 2010; Palla et al. 2011). These studies reported exuvia belonging to the superfamily Chthonioidea from the abdominal cavity of Namenkhet Amun, an Egyptian mummy (Huchet 2010) and a single chela from an unknown species of pseudoscorpion collected during an analysis of mummified material (Palla et al. 2011). The present study therefore documents the first occurrence of pseudoscorpions belonging the family Cheiridiidae to be reported from ancient Peruvian burials.

Members of the family Cheiridiidae were first recognized as a group known as the Cheiridiinae by Hansen in 1894 for the genus Cheiridium Menge, 1855 and was treated as belonging to the family Cheliferidae. In 1931, Chamberlin elevated this group to the family level, calling them the Cheiridiidae, which

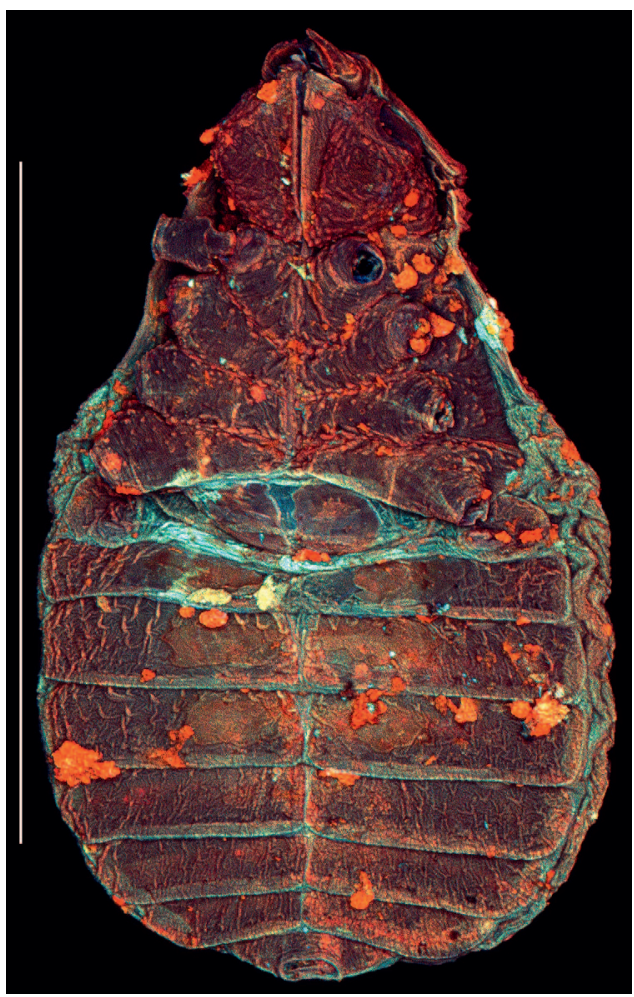

Figure 3.-Confocal laser scanning microscopy image of the ventral view of a pseudoscorpion recovered from Pachacamac sample P17. Scale bar $=500 \mu \mathrm{m}$.

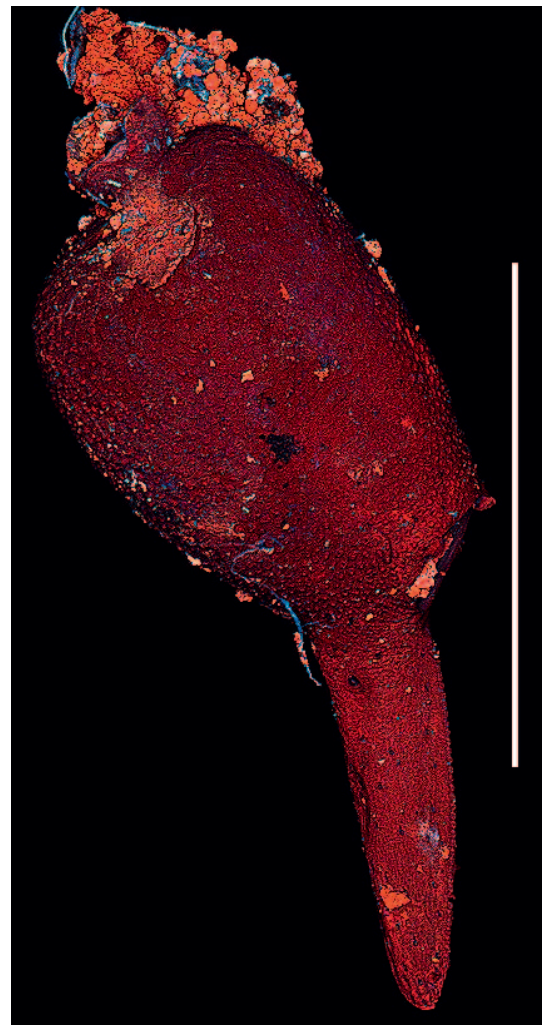

Figure 4.-Confocal laser scanning microscopy image of a disarticulated pseudoscorpion pedipalp recovered from Pachacamac sample P17. Scale bar $=500 \mu \mathrm{m}$. 
now includes two subfamilies: the Cheiridiinae (five genera) and the Pycnocheiridiinae (two genera). Additionally, the genus Electrobisium Cockerell, 1917, which is known only from Burma amber deposits dating to the Upper Cretaceous, belongs within the subfamily Cheiridiinae. Members of the Cheiridiidae are widely distributed, though a few are restricted to South Africa (Pycnocheiridium Beier, 1957), tropical South America (Leptocheiridium Mahnert \& Schmidt, 2011), and the western Pacific (Nesocheiridium Beier, 1957). The genera Apocheiridium Chamberlin, 1924, Cheiridium, Cryptocheiridium Chamberlin, 1931, and Neocheiridium Beier, 1932 are reported from multiple continents. The pseudoscorpions from Pachacamac are not morphologically consistent with Apocheiridium (Beier, 1964; Benedict 1978), but could potentially belong to Cheiridium or Neocheiridium, both of which are known to occur in the Americas.

Members of the family Cheiridiidae have not been previously reported from Perú (Harvey 2013); however, Cheiridids have been found in other South American countries, including Argentina, Brazil, Chile, Colombia, Ecuador, and Paraguay (Harvey 2013; Quirós-Rodríguez et al. 2015). The incomplete nature of the invertebrate record in Perú makes it unclear whether pseudoscorpions recovered in the present study are unreported although native to this region, or if these specimens represent transported non-native species. Pachacamac was a site of religious significance, housing the human remains of individuals who are likely to have lived in geographic locations far from the site. Historic sources describe pilgrimages of the living to Pachacamac made by ancient people residing some 1,600 kilometers away (Bauer \& Stanish 2001). If these pseudoscorpions did not come to the burials after corpses were interred, then it is possible that they were transported either by humans or other animals, such as scavengers.

Pseudoscorpions are voracious predators of mites and small insects that may be attracted to human corpses. There would be no shortage of prey items for these predators at Pachacamac as corpses were quickly infested by a wide range of flies and beetles that produce larvae within decomposing flesh. A variety of mites are also encountered in forensic analyses of corpses. The specific roles of mites as members of the corpocenosis are still under investigation in modern contexts. These investigations will be helpful in elucidating the roles of these arthropods as members of the archaeological corpocenosis. A few studies have begun characterizing mites recovered from archaeological contexts to further elucidate the nature of their presence within coprolites, mummies, and archaeological sediments (Morrow et al. 2013, 2016). These mites could be brought to the corpses via phoresy utilizing flies, beetles, or other necrophagous insects or predators of necrophagous insects. Mites are themselves excellent prey items for pseudoscorpions present at corpses. Subsequent analyses of the burial sediments from Pachacamac (unpublished data) have revealed some samples to have mites that remain unidentified at the present time; however, no mites were recovered from samples P7 or P17, which did contain fragments of pseudoscorpions. Like these prey, pseudoscorpions are able to be dispersed via phoresy utilizing a wide range of insects for transportation (Perotti et al. 2010, Poinar et al. 1998). Some pseudoscorpions are even known to use vertebrates, such as birds (Turienzo et al. 2010), as transport hosts arriving at corpses.

The present study reports the first members of the pseudoscorpion family Cheiridiidae to be recovered from archaeological contexts. Specimens from this study were quantified using a novel technique for reporting pseudoscorpion concentrations and the MNI among the samples analyzed. Additionally, the employment of Auto-Montage stereomicroscopy and confocal laser scanning microscopy has demonstrated the practicality of using these techniques to assist with the taxonomic identification of arthropods recovered from archaeological contexts. As future archaeoarachnological studies examine pseudoscorpion and other arachnid remains from coprolites, mummies, and burial sediments, it is advisable for these studies to employ similar methods for quantification and identification. Such studies would provide comparative data vital for the characterization of the archaeological corpocenosis.

\section{ACKNOWLEDGMENTS}

Auto-Montage images in this research were taken in the Biodiversity Synthesis Laboratory of the University of Nebraska State Museum (NSF/BS\&I Multi-user Equipment grant DBI 0500767 to M. L. Jameson and F. C. Ocampo). The authors thank Shawn Shumaker for his advice on the project and the Forensic Science Program at UN-L for providing stereomicroscopes used for counting and sorting specimens. The authors also thank Dr. Mark Harvey for his valuable assistance with specimen identification.

\section{LITERATURE CITED}

Bauer, B.S. \& C. Stanish. 2001. Ritual and Pilgrimage in the Ancient Andes. Austin: University of Texas Press.

Beier, M. 1964. Die Pseudoscorpioniden-Fauna Chiles. Annalen des Naturhistorischen Museums in Wien 307-375.

Benedict, E.M. 1978. False scorpions of the genus Apocheiridium Chamberlin from western North America (Pseudoscorpionida, Cheiridiidae). Journal of Arachnology 5:231-241.

Berg, G.E. 2002. Last meals: recovering abdominal contents from skeletonized remains. Journal of Archaeological Science 29:13491365.

Eeckhout, P. 2000. The palaces of the Lords of Ychsma. An archaeological reappraisal of the function of pyramids with ramps at Pachacamac, central coast of Peru. Journal of American Archaeology 17-18-19:217-254.

Eeckhout, P. 2003. Ancient monuments and patterns of power at Pachacamac, central coast of Peru. Beiträge zur Allgemeine und Vergleichenden Archäologie 23:139-182.

Eeckhout, P. 2013. Change and permanency on the coast of ancient Peru: the religious site of Pachacamac. World Archaeology 45:119142.

Eeckhout, P. \& L.S. Owens. 2008. Human sacrifice at Pachacamac. Latin American Antiquity 19:375-398.

Eeckhout, P. \& L.S. Owens. 2015a. The impossibility of death: introduction. Pp. 1-11. In Funerary Patterns and Models in the Ancient Andes: The Return of the Living Dead. (Eeckhout, P. \& L.S. Owens (eds.)). Cambridge University Press.

Eeckhout, P. \& L.S. Owens. 2015b. Funerary Practices and Models in the Ancient Andes. Cambridge: Cambridge University Press.

Fleming, S. 1983. The mummies of Pachacamac. Expedition 28:3945.

Harvey, M.S. 1992. The phylogeny and classification of the 
Pseudoscorpionida (Chelicerata: Arachnida). Invertebrate Taxonomy 6:1373-1435.

Harvey, M.S. 2013. Pseudoscorpions of the World, version 3.0. Western Australian Museum, Perth. Online at http://www. museum.wa.gov.au/catalogues/pseudoscorpions

Huchet, J.B. 2010. Archaeoentomological study of the insect remains found within the mummy of Namenkhet Amon, San Lazzaro Armenian Monastery, Venice/Italy. Advances in Egyptology 1:5980.

Legg, G. \& R.E. Jones. 1988. Synopses of the British Fauna (New Series). 40. Pseudoscorpions (Arthropoda). Brill/Backhuys, Leiden Morrow, J.J., J. Newby, D. Piombino-Mascali \& K.J. Reinhard. 2016. Taphonomic considerations for the analysis of parasites in archaeological materials. International Journal of Paleopathology 13:56-64.

Morrow, J.J., D. Piombino-Mascali, D. Lippi \& K.J. Reinhard. 2013. Archaeoparasitological analysis of viscera from the Medici family (Saint Lorenzo Basilica, Florence, Italy). Medicea.

Owens, L.S. \& P. Eeckhout. 2015. To the god of death, disease and healing: social bioarchaeology of cemetery I at Pachacamac. Pp. 158-185. In Funerary Patterns and Models in the Ancient Andes: the Return of the Living Dead. (P. Eeckhout, L.S. Owens (eds.)). Cambridge University Press, Cambridge.

Palla, F., L. Sineo \& B. Manachini. 2011. Bacteria, fungi and arthropod pests collected on modern human mummies. Journal of Entomological and Acarological Research 43:69-76.
Perotti, M.A., H.R. Braig \& M.L. Goff. 2010. Phoretic mites and carcasses: Acari transported by organisms associated with animal and human decomposition. Pp. 69-91. In Current Concepts in Forensic Entomology (J. Amendt, M.L. Goff, C.P. Campobasso, M. Grassberger (eds)). New York: Springer Science \& Business Media.

Poinar, G.O., Jr, B.P.M. Curčić \& J.C. Cokendolpher. 1998. Arthropod phoresy involving pseudoscorpions in the past and present. Acta Arachnologica 47:79-96.

Quirós-Rodríguez, J.A., E. Bedoya Roqueme \& R. Bedoya Cochett. 2015. Primer reporte de la familia Cheiridiidae en Colombia. Acta Biologica Colombiana 20:217-220.

Reinhard, K.J., U.E. Confalonieri, B. Hermann, L.F. Ferreira \& A.J. Araújo. 1986. Recovery of parasite remains from coprolites and latrines: aspects of paleoparasitological technique. Homo 37:217239.

Turienzo, P., O. di Iorio \& V. Manhnert. 2010. Global checklist of pseudoscorpions (Arachnida) found in birds' nests. Revue Suisse de Zoologie 117:557-598.

Uhle, M. 1903. Pachacamac. Report of The William Pepper, M.D., LL.D. Peruvian Expedition of 1896. The Department of Archaeology of the University of Pennsylvania, Philadelphia.

Manuscript received 22 January 2017, revised 17 April 2017. 